\title{
Impact of the Covid-19 Pandemic on the Global Economy
}

Lustov N.S.

Department of Economics and Enterprise Management, Karaganda Technical University, Kazakhstan.

Corresponding Author: Lustov N.S, Department of Economics and Enterprise Management, Karaganda Technical University, Kazakhstan. Received date: April 13, 2021; Accepted date: April 26, 2021; Published date: May 03,2021

Citation: Lustov N.S. (2021) Impact of the Covid-19 Pandemic on the Global Economy. Journal of Clinical and Laboratory Research. 2(4) DOI: $10.31579 / 2768-0487 / 019$

Copyright: (92021 Lustov N.S. This is an open-access article distributed under the terms of the Creative Commons Attribution License, which permits unrestricted use, distribution, and reproduction in any medium, provided the original author and source are credited.

\section{Abstract}

The article describes the global trends that characterize the development of the economy in 2020. The main economic results of 2020 are presented. Conclusions are drawn regarding the main trends in 2020 due to the coronavirus pandemic. The points of view of foreign and domestic researchers on the pandemic and its consequences are presented.

Keywords: world economic crisis; the world bank; Covid-19; pandemic; economic development

\section{Introduction}

In 2020, the global economy faced a new crisis phenomenon, which was called first in the media and then in the scientific literature "coronacrisis", which mainly indicates the trends of 2020 and the socioeconomic consequences of the COVID-19 pandemic. In this situation, there is a need to explain and theoretically substantiate the processes taking place in the world economy. The problem is the lack of a systematic approach to describing trends in the world economy. The object of research in this article is the world economy at the turn of 20202021. The subject of the research is the development of a set of modern processes in the global economy in 2020 due to the COVID-19 pandemic. The new crisis in the global economy associated with the COVID-19 pandemic could not be objectively predicted by researchers and is not associated with any periodicity or cyclicality. At the same time, in 2020, due to strict restrictions imposed by the governments of countries to slow the spread of the new virus, economic activity virtually stopped all over the world.

\section{The results of the COVID-19 pandemic for the global economy}

Undoubtedly, the first and most negative consequence of the pandemic for the global economy should be called the presence of a large number of human deaths from both the COVID-19 virus itself and from its consequences, as well as an increase in mortality due to the presence of chronic diseases and congestion of the healthcare system. It is not possible to draw a final conclusion about the loss of human capital at this stage due to the actual incompleteness of the coronavirus pandemic.

The second negative consequence of the COVID-19 pandemic is, in our opinion, the widespread economic recession. This phenomenon is inherent in any other global economic crisis. For example, the World Bank's Global Economic Prospects report [1] describes both the immediate and short-term prospects for the impact of the pandemic on the global economy, as well as the long-term damage that it has done in terms of the potential growth prospects of the world economy. The baseline projection foresees a $5.2 \%$ reduction in global GDP in 2020, which means the deepest global recession in decades, despite the enormous efforts of the world's governments to counter the economic slowdown with the help of financial and monetary policies, as well as various measures to support economic agents and households.

In addition, this deep recession, triggered by the COVID-19 pandemic, appears to have an even more negative impact in the long term due to reduced investment, human capital due to job and training losses, and fragmentation of global trade links and international supply.

The crisis that began in 2020 is a marker of the need for urgent action to mitigate the impact of the pandemic in terms of protecting vulnerable populations and entrepreneurship.

The 2020 pandemic is expected to plunge most countries into a prolonged recession due to projected reductions in per capita income in most of the world: advanced economies by 7\%; for emerging market and developing countries, this figure is $2.5 \%$, which will be the weakest indicator for this group of economies over the past 60 years $[2,3,4,5]$.

It is expected that this downturn for emerging market and developing countries will trigger various economic obstacles: pressure on health systems, loss of trade and tourism, reduced remittances. Exporters of energy or manufactured goods will be particularly hard hit, especially as the pandemic and efforts by governments to contain it have caused an unprecedented collapse in oil demand and a drop in oil prices. Demand for metals and transportation-related goods such as rubber and platinum used for auto parts also fell. While agricultural markets around the world are well-stocked, trade restrictions and supply chain disruptions can cause food security problems in some places.

However, the World Bank also predicts a scenario of a moderate recovery of global economic growth to $4.2 \%$ in 2021.But this forecast will be unlikely if restrictions on movement are extended or reintroduced, and in the event of an extension of disruptions in economic activity - in the form of regular lockdowns. 
The third result of 2020 should be considered a collapse in oil prices. Low oil prices may, at best, provide temporary initial support to growth once restrictions on economic activity are lifted. But even after demand recovers, the adverse impacts on energy exporters could outweigh any potential benefits to energy importers.

However, it should be noted that the very positive results of the introduction of restrictive measures in the global economy in 2020. Thus, the COVID-19 pandemic has strengthened all aspects of the digitalization of the world economy, accelerating its passage. The global economic crises of previous years have never yielded results of this kind: all aspects of society, from education to healthcare, have shifted to the digital plane.

For example, in OECD countries the volume of work, e-commerce and distance learning, as well as the use of digital tools in business, have grown dramatically. Governments, business leaders and academia quickly recognized the potential of artificial intelligence and the need for timely, secure, and reliable access to data. However, any remote activity relies on Internet access and requires modern technical connectivity, which is driving the growing demand for high-quality Internet connectivity, reinforcing the need for a more comprehensive approach to digital transformation. In turn, the ease and availability of remote working methods creates a favorable environment for cybercriminals. This situation also contributes to the need for a quick response. Thus, 34 OECD member countries have a national digital development and security strategy, 24 of which adopted the latter in 2020 [6] as a response to the potential risks and threats of accelerated digitalization of the economy.

The answer to the question "why the spread of the coronavirus brought the world economy to its knees" is given by P.K. Ozili and T. Arun. According to scientists, the answer lies in two methods by which the coronavirus suppressed economic activity. First, the spread of the virus has spurred social distancing that has led to the closure of financial markets, organizations, corporate offices and events. Second, the exponential speed of the virus and heightened uncertainty about how dire the situation could become have led consumers, investors and international trading partners to flee to safe conditions of consumption and investment.

The researchers also note that the high costs of implementing fiscal policy during the pandemic in the countries of the world had a positive effect on the level of economic activity, in contrast to the increase in the number of confirmed cases of COVID-19, which did not significantly affect the level of economic activity [7].

\section{Conclusions}

The most important negative impact of the COVID-19 pandemic is the loss of human resources and human capital.

At the same time, positive trends should also be highlighted, for example, the accelerated digitalization of not only the economy, but also all spheres of society, but this trend can also be considered in the context of a risk factor due to the increased incidence of fraud and increased cybercrime and requires measures at the level of state legislation to prevent negative consequences.

\section{References}

1. Pandemic, Recession: The Global Economy in Crisis.

2. The Global Economic Outlook During the COVID-19 Pandemic: A Changed World.

3. Food and Agriculture of the United Nations.

4. Volkov S.N. (2018) Tkachenko A.A. North Africa: economic development and modernization processes Asia and Africa today. No 12.P. 37-41.

5. Prospects for the development of the regional economy: (2020) The Middle East and Central Asia

6. The COVID-19 pandemic has amplified all aspects of the digital transformation.

7. Ozili P.K., Arun T. (2020) Spillover of COVID-19: Impact on the Global Economy.

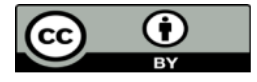

This work is licensed under Creative Commons Attribution 4.0 License

To Submit Your Article Click Here: Submit Manuscript

DOI: $10.31579 / 2768-0487 / 019$
Ready to submit your research? Choose Auctores and benefit from:

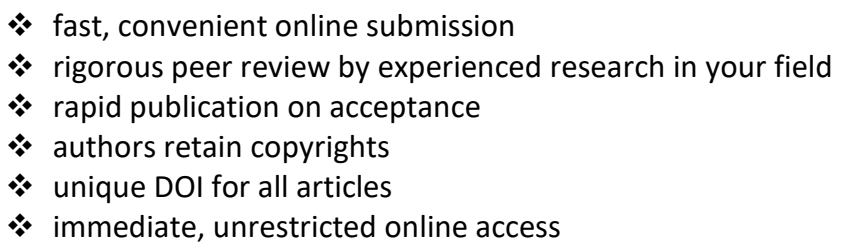

At Auctores, research is always in progress.

Learn more www.auctoresonline.org/journals/journal-of-clinical-andlaboratory-research 